\title{
Katarzyna Kopecka-Piech*
}

\section{MEDIA INFILTRATION - URBAN MEDIA IN SPACE AND TIME}

\begin{abstract}
The article examines relations between new media and the city in spatial and temporal dimensions. A process of media infiltration is analyzed using several examples and illustrations. Spatial infiltration is characterized by a created typology of physical, virtual and augmented media infiltration. It describes some of the processes of personal and social semiotization, as well as visibility, invisibility and quasi-visibility of media elements as typical features of media infiltration. The reflection on this leads to an explanation of complex relations between spatial infiltration and hybrid time emerging from new media usage. Tempo, rhythm and acceleration represent categories of the complex relations between mobility, temporality and spatiality. The article analytically explores creative, social and technological possibilities of new urban media and mediated practices, rather than indicating the critical implications of them.
\end{abstract}

Key words: new media, mobile media, urban media, media infiltration, media space, hybrid time

\section{INTRODUCTION: SPACE, TIME AND URBAN MEDIA}

Relations between media and cities have become more and more sophisticated. A number of new media tools and services are being applied in urban spaces to create converging media spaces where new media intensively determine the filling and structurization of the users' time (Kopecka-Piech 2012). There are two main types of new media present in urban space: stationary (used in a fixed location) and mobile (used on the move). Because of their number, effects, relations between them and importance for the users we can say that both stationary and mobile new media infiltrate the city. They penetrate material and digital structures of the city, which results in new forms of urban space. Stationary and mobile media converge because of multiplatform content, which is cross-promoted and usually socially shared and created. Very often social media play the role of a "clip", girding different media platforms dispersed in an urban physical and virtual space. Stationary media determine physical space more than virtual ones. They are tangible, material in their nature so their effects are also material - they change the visual site of the city, create new visible infrastructures that integrate it. Their influence is much more spatial than temporal. Stationary urban media do not "drain" the users' time as intensively as mobile media do. They might engage users and demand their time, but it is determined by the space, the location of the medium. "Mobile urban media" (Kopecka-Piech 2012: 111) infiltrate the city in its temporal dimension regardless of the location of the device.

\footnotetext{
* University School of Physical Education in Wroclaw; katarzyna.kopecka.piech@gmail.com
} 
Moreover, mobile media determine the virtual space of the city much more than stationary media, because they create the invisible urban networks: informational and social networks which enable one to annotate the physical space, hybridize it and augment it. Mobile urban media are to a large degree responsible for the users' time structuring by influencing daily activities (working, shopping, entertaining) - doing them on time, by moving faster, filling the free time, etc. Spatial and temporal infiltration of both types of media results in new forms of a city: mediatized, hybrid and converged.

\section{SPATIAL INFILTRATION}

Media content, technology and organization penetrate the fabric of the city, and its urban material and digital structures. Media infiltration is a process of penetration and drainage of the city by the media and establishing the infrastructure of converging media spaces: spaces merging and hybridizing physical and virtual spaces through the media (Kopecka-Piech 2012).

\section{PHYSICAL INFILTRATION}

Physical infiltration is the first dimension of the spatial infiltration and it takes place when media objects become built into the material infrastructure of the city, such as a television screen or an interactive built-in computer as a part of a building wall (Fig. 1). Most often it is contact that allows delivery of commercial information or a work of art - to arouse curiosity, stimulate interaction, and turn attention towards a different media platform like popular social media. This is the most frequent and easiest way of integration - a shop window becomes a "window" for Facebook or Twitter content. Occurrence of so-called "urban screens" (Struppek 2006: 174; Krajina 2009: 401) leads to urban space infiltration by traditional media like television, which transmits important events on large screens in the city center, favoring the integration of inhabitants and tourists. Along with the application of the QR codes or references to Internet websites (such as the ubiquitous "like it" typical of Facebook), the screens become unlimited when it comes to content, and at the same time, they "become less a screen than a membrane between physical and virtual reality" (Kluitenberg 2006: 12). They may carry an unlimited amount of data thanks to the in-betweens, what is between the screen and the Internet website: the virtual data base.

Media façades or media buildings (McQuire 2010: 5) are more sophisticated forms of media and urban space infiltration. Unusual arrangements of buildings, light, sound and animation are often interactive and involve people, or at least arouse curiosity among the passers-by (Fig. 2). These arrangements reflect the relationship between real and virtual architecture and correspond to recipients' activity by emitting e-mails and logotypes of brands, or they serve as screens for mobile phone games. Sometimes they are integrated with traditional media content (e.g. music and narration on the radio), internet content throughout QR codes (Schielke 2010) or real time video streaming on a building wall from a different location. They are the best examples of the culture of overlay (Kopecka-Piech 2012: 85-86) and "the spatial experiences of streetscape and datascape" (McQuire 2009: 5). 


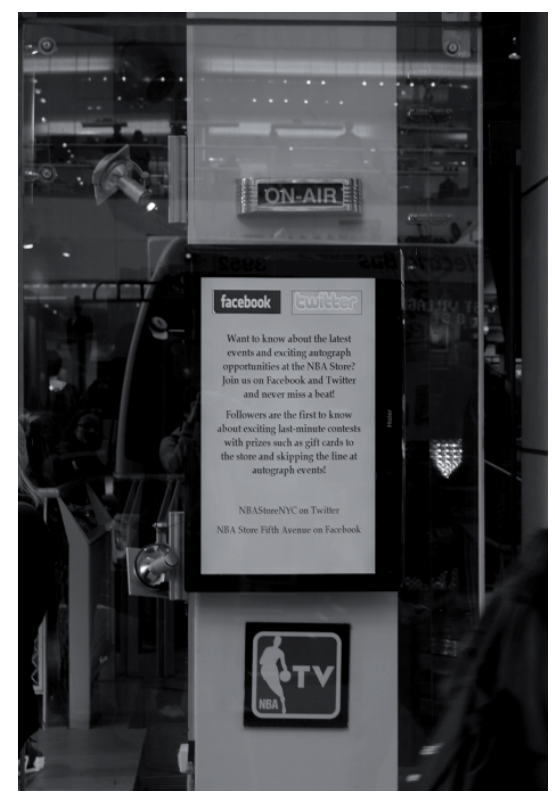

Fig. 1. New York City. NBA Store shop window
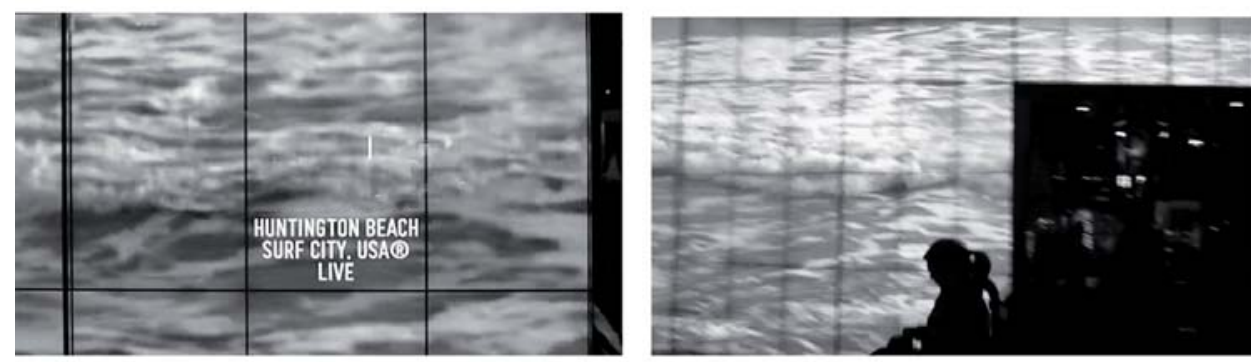

Fig. 2. New York City, Opening of the Hollister (clothing) Co. shop screens on the building's façade transmit a live view of waves from Huntington Beach, California

Infiltration in the physical dimension reflects the media architecture of commerciality, a typical metropolitan convergence of architecture, which combines the material with the virtual in a new type of experience of mediatized urban space. This type of architecture often involves people through the use of applications, codes, interactive systems or in other mediated ways - by giving passers-by the opportunity to take part in an undertaking which results in media effect, such as by posing for photographs to become an element of a real-life storefront or create media content visible not only online but also offline (Fig. 3). Physical infiltration is material in its infrastructure and equipment but it is digital or hybrid in its interface and content. 


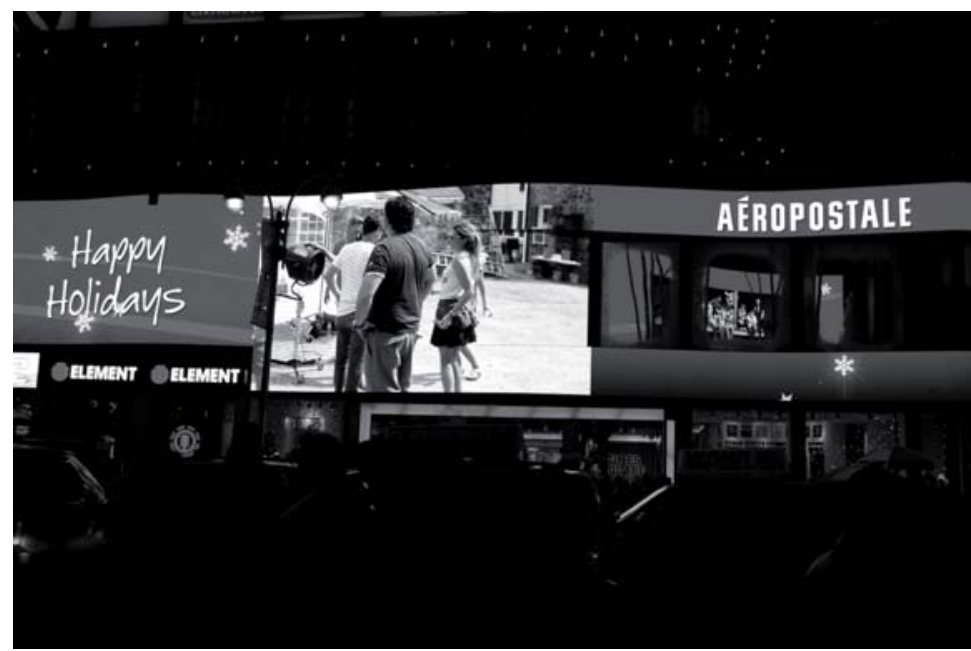

Fig. 3. New York City, Times Square, Aeropostale (clothing company) shop window: combination of screens, neon lights, and a shop window in which customers are photographed with Santa Claus and become a part of the storefront

\section{VIRTUAL INFILTRATION}

Media infiltrate not only the infrastructure, physical façades and the structure of buildings and streets. They also infiltrate through specially designed multiplatform content. Virtual permeation should be understood as generating a link between the content and form present in the physical urban space, and the virtual content and form. The link is created as a result of linking the material space and the cyberspace.
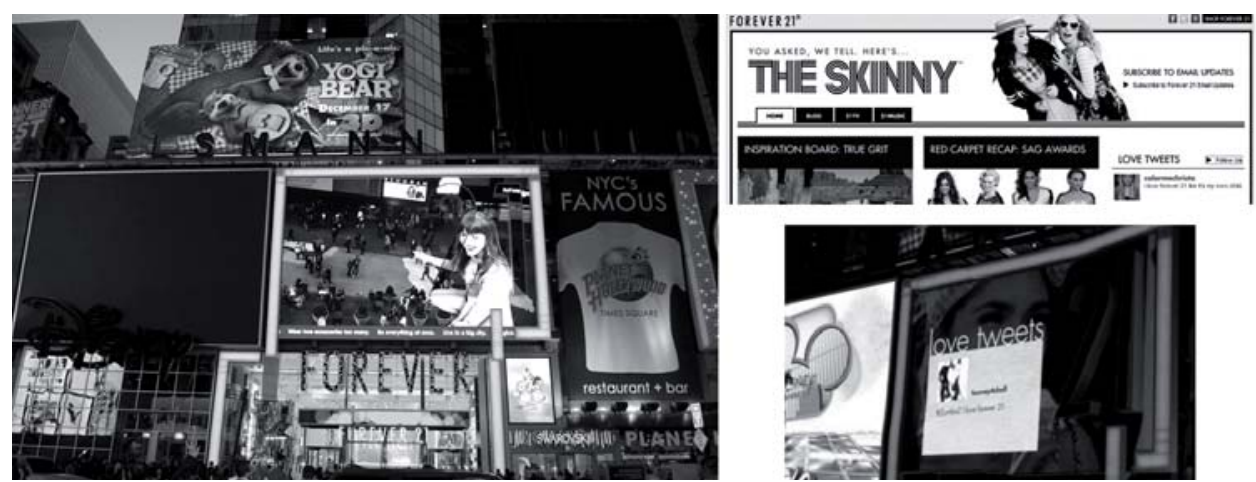

Fig. 4. New York City, Times Square, Forever 21 (clothing company) digital billboards; Upper right: Forever 21 official webpage print screen (with 'love tweets') 
Converging media space created by the Forever 21 ad campaign in Times Square associates physical space and digital space (Fig. 4). People can become a part of the digital billboard by standing in a certain place on the square and allowing themselves to be recorded. A photo or a real-time video is placed on the huge screen over the shop entrance. Passers-by can also become co-authors of the billboard catchwords via Twitter, posting "love tweets" which appear on the official web page. Users' activity is a kind of play connecting several distinctive processes: socialization, commercialization, produsage ${ }^{1}$ (Bruns 2006: 275) and spatialization (Lemos 2008: 91). People use media platforms and create the content. Their activity is based on social network pages (like Twitter) and is used for advertising by creation of provisional hybrid places. Forever 21's "platform-palette" (Bechmann-Petersen 2007: 71) is transmedia, interactive, real-time and asynchronous, visual and textual at the same time. It exists in a physical layer (the square), a digital layer (the billboard) and a cyber layer (the web page). The initial contact may take place in the physical layer or the cyber one and can be multilateral (Fig. 5).

"Media-palettes" also generate one-way communication acts, e.g. from physical to digital. The digital billboard projection of QR codes which can be read on the street via mobile phones with cameras, and their appropriate application is an example of association of the physical and digital layers. The users' activity does not make any change in the relations between layers. By taking a photo of the QR code and by the process of transformation with the application on a mobile phone, additional information is delivered onto the phone screen. The user can then read more about a product or service.

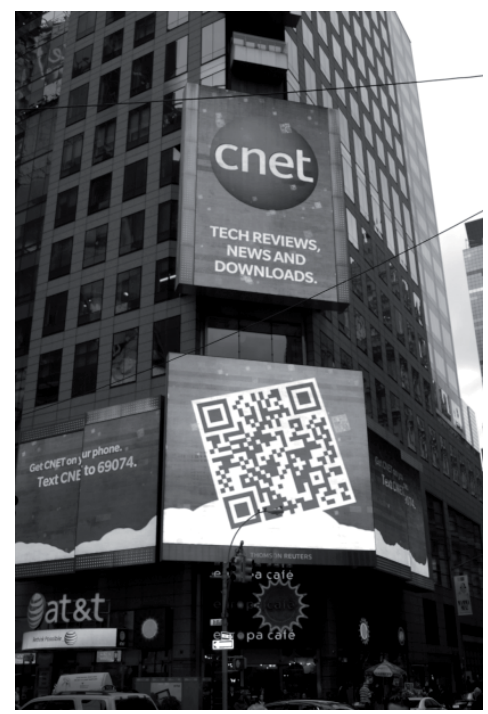

Fig. 5. New York City, Time Square, CNET advertisement

1 "Produsage - the collaborative and continuous building and extending of existing content in pursuit of further improvement" (Bruns 2006: 276). 


\section{MERGING INFILTRATIONS: THE CASE OF THE NIKE+ "UNIVERSE"}

Virtual infiltration often combines physical infiltration with the daily activities of the users. Nike+ is a brand of associated products: shoes (with sensors), special watches, bands, and a GPS application for iPhone and Android which is integrated not only with Nikeplus.com but also with Facebook and Twitter. All the equipment (material objects and digital services) creates a branded universe. It allows runners to control their training sessions and to get support from others ("Cheer Me On") and also to compete ("Nike+ Route Boss"). The activity of over two million runners around the world results in the creation of a very specific hybrid space, virtual and real, but also personal and social. Runners log in to the Nike+ webpage, put their favourite routes on the map and compete for the best results. Their personal results are delivered by Nike+ equipment and might be controlled in real time by the runner and other members of the community. The process of the creation of converging media spaces is based once again on socialization, commercialization, produsage and also territorialization. The last occurs by mapping activity (Lemos 2008). André Lamos (2008) introduced the term "informational territories", which are "areas where informational flow, in the intersection between cyberspace and urban space, is digitally controlled". Nike+ generates a number of informational territories which are "inhabited" by runners. Runners not only go through but "compose" those territories (Brighenti 2011: 406) (Fig. 6).

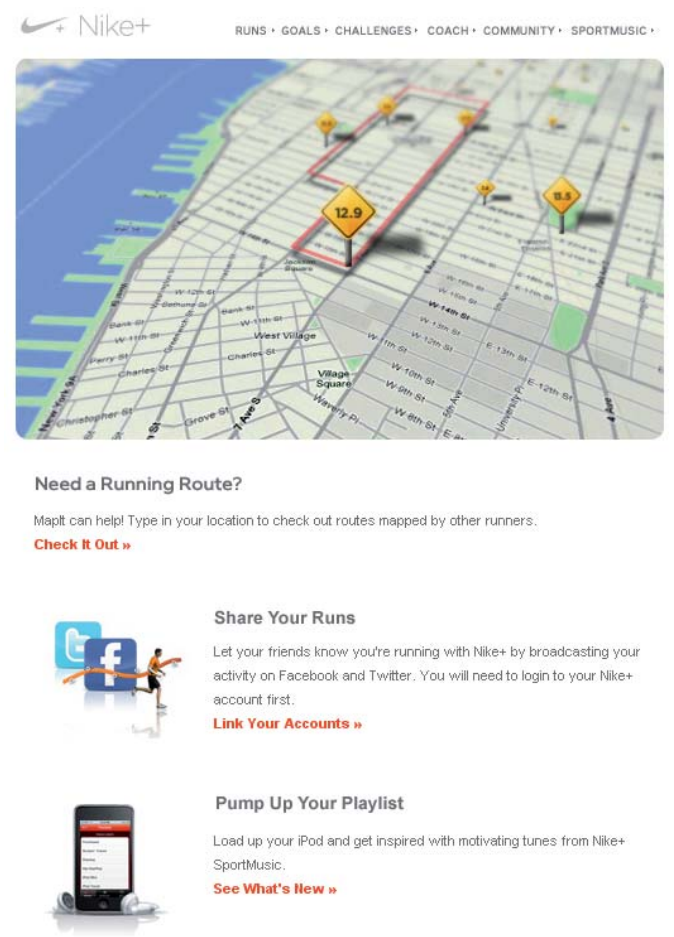

Fig. 6. Nike+ newsletter for runners, 26.03.2011 


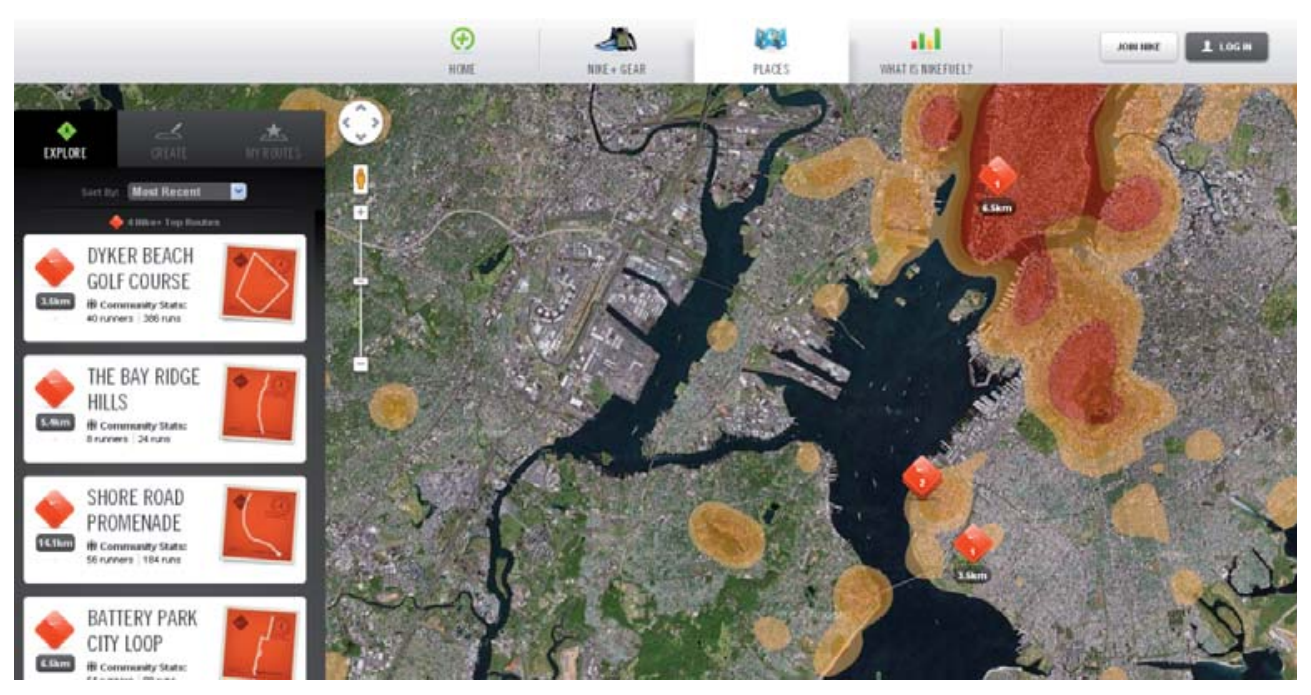

Fig. 7. Examples of the Nike+ routes in Manhattan, http://nikeplus.nike.com/plus/places/\#/Explore/ 40.64914429822358/-74.07413276889874/12, 2.10.2012

Creation of "informational territories" is accompanied by the process of customization (whereby clients can design their shoes, or complete their equipment choosing from a variety of devices and garments) but first of all customers can personalize their mediated activity ${ }^{2}$. They choose a route or create their own, invite friends and analyze their support via social network services (Fig. 7). They may compete or join a benevolent activity such as a charity run, or take part in global campaigns like "Share your game with the world" or "Greatness is ours". Their activity is local and global at the same time. Informational territories created by the activity of the runners have a glocal character. Rankings of different places where users run, such as a city park, are created. People create their own territories and participate in global initiatives at the same time. Nike+ represents the model of the creation of a mobile media environment which infiltrates the city on the virtual and material level. The network of running routes is applied to a digital map of the city which creates its own "universe" of branded and mediated community. The real streets of the city become inhabited by the runners equipped with special media gadgets. Users infiltrate the physical layer of the city themselves by being on the move and constantly using media (Fig. 8).

2 There is a question whether mediated urban activity is even possible. It is potentially possible in disconnected spaces like zones of privacy, prevented from GPS, television, internet, telephone and other transmission and emission; and providing shielding from security cameras and surveillance satellites, e.g. Floatables experiment (Labetskaya 2011: 47). 


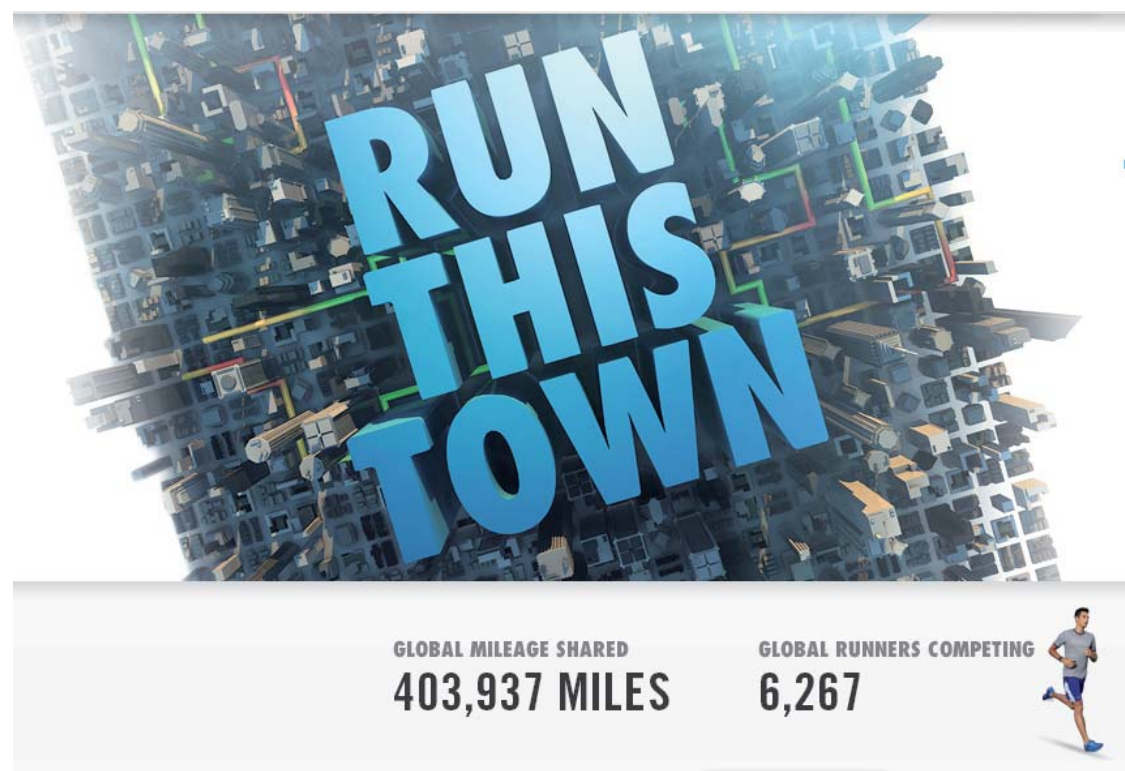

Fig. 8. "Run this town" action results in the ranking lists of countries and cities of the most active runners, http://gameonworld.nike.com/?cp=gbnp_em_072712_ESPUS\&et_cid=62729\&et_rid= 2101393369392\&et_sid=EGPJ0727NPESP_GP_ESP_aUS\#en_US/mission/runthistown, 2.10.2012

\section{AUGMENTED INFILTRATION}

Apart from physical infiltration and virtual infiltration users also experience an augmented reality, thanks to applications for mobile devices, Application databases storing data on nonexistent objects (data, which are projected on real space by the means of devices like smartphones, tablets) here play the role of in-betweens. Augmented space is a hypothetical space, particularly changeable, more and more attractive for both the recipients and the senders: suppliers of information, advertisers, and traders.

The merger of physical and digital layers takes place in augmented reality solutions, like the "New York Newest Subway" iPhone application, which allows users to find the closest subway station by displaying on the screen the superposition of virtual lines of the subway on the scanned real surroundings. Applications like "NYC Way" associate the physical space, the cyberspace and the space which could be called the digital mobile space, because it is available on a mobile device only. The part of "NYC Way" is the "Live Traffic Cams" - a subapp allowing a traffic preview of chosen cross-roads in the city. The user needs to choose the destination or go to Google Maps to use it. A real time video from the indicated place is streamed onto the screen. The real time preview establishes the association of two (or more) 
places of the physical layer, the mobile layer, the cyber layer and a map. The map is an intermediary of this hybrid relation. Applications such as Layar or Wikitude have a similar function. Wikitude is "an Augmented Reality Browser [which] scans your surroundings for (e.g.) geo-referenced content using the camera and the device's sensors. The objects' information is displayed in the cam right where the real object is located" (Wikitude). "Layar displays digital information called 'layers' in a user's field of vision through their mobile device. The Layar API supports (...) interactivity, including audio and visual elements, 3D models, and social sharing capabilities" (Layar). It is a browser of points of interest based on layers placed on a video camera image. Those layers consist of graphics, animations, and so on. Users enrich the content with descriptions, evaluative comments, and more.

Augmented reality applications enable users to create their own hybrid spaces, partially virtual and material, with removable elements and selected information delivered by mobile services on demand. Augmented Reality leads to unlimited possibilities of infiltration of every object located in the city. Every bench in a park, shop window or tram station might hide information unlimited in content and form, and be subjected to a process of personalization.

\section{INDIVIDUAL AND SOCIAL SEMIOTIZATION OF THE SPACE}

Urban media semiotization is the most personal kind of semiotization, but at the same time it reaches to the very roots of the community. It makes physical places significant in the virtual space through "performative mapping" (Gemeinboeck, Dong and Veronesi 2007: 12) or subjective marking of the urban space. The roots of semiotization reach into novels, in which the action takes place in non-existent but possible to experience places. The traditional medium, the book, despite its many virtues is now being unidirectionally replaced by interactive community storytelling initiatives like "New York Writes Itself", which gives the opportunity to describe one's own experience of city life in real time and in widely and globally accessible cyberspace. The content of the diary entries may later on become the content of a film placed on the webpage that has started the initiative. Social media narration fulfills the need of self-publishing, co-creation and simultaneous identification with a place and its promotion. "The changing city does appear to be moving more toward the virtual mediated metaphorical and mechanical mental images that continue to be projected from its geographical spaces" (Burd 2007: 41). Semiotization also manifests itself in the created narration, such as cartographic narration. Foursquare exemplifies this process when users check in to places and document their presence by photos, videos, comments and tips. Sharing of media content by users makes the places valuable for themselves and others. They create their own list of worthwhile places and simultaneously create a community along with other application users. "Foursquare can be seen as the creation of a cultural map, depicting the places seen as relevant to the people experiencing them" (Gazzard 2011: 409) (Fig. 9). 


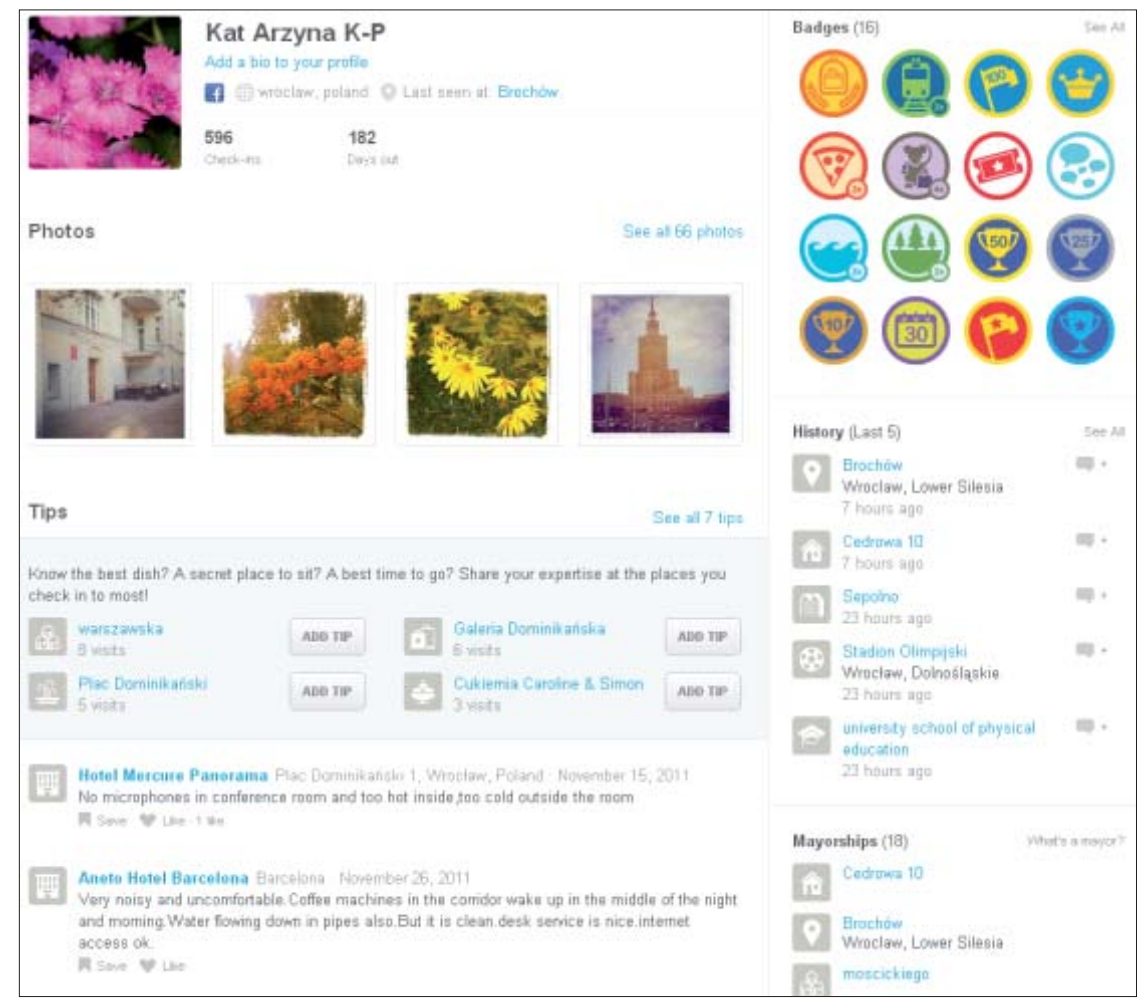

Fig. 9. Example of a Foursquare profile including information about the activity of the user, https://foursquare.com/user/5131950, 4.10.2012

\section{VISIBILITY, INVISIBILITY AND QUASI-VISIBILITY}

We could conceptualize a mediated urban space as a multiplicity of overlapping spaces which are physical, virtual, augmented, individual and social. In this context, we could say that not only the double space (according to "doubling of space" (Scannell 1996: 172) but also multiplied spaces exist and let users experience more than one or two places at the same time. This is an annexed space, personalized and socialized at the same moment.

All layers, physical, virtual and augmented, become similar, closer, dependent. The city becomes a social event, a social and technological process but also a personal and social experience: a complex of mediated events, flows and overlapping layers. The relationship between converging spaces is changeable and in the temporal dimension, oriented on acceleration and automaticity. Infiltration subjects appear and disappear depending on the trends, their popularity and usefulness. Thus, once they are visible, and then they are invisible. They become invisible because either they have not been activated (like augmented reality objects), they 
have been removed (like interactive city lights), or they are not used at all. For that reason, convergence here might be understood as a process of appearance and disappearance; the usage and abandonment of widgets, applications, devices, products, and such, making certain urban space elements visible or invisible. When buildings are subjected to media infiltration and hide their façades under multimedia illumination, in a way they vanish in their original form. By contrast, information on the building's history emerges as an overlay on physical reality while using interactive maps. The content is hidden as long as it is not recalled by means of digital media. Because of the direct technological link with the material space, the augmented reality elements may be described as quasi-visible: they are visible only within the image recorded by the video camera; without it they cannot be used. Consequently, it may be claimed that being in a certain space and using certain devices or applications enables a user to differentiate this space and multiply it through elimination or overlaying particular elements. Personal and social context plays a vital role in conversion of urban spaces, because the final effect achieved by a person present in the urban space depends on the kind of device and application used, the kind of commercial or promotional action performed, urban external surroundings, other users' activity and competence, and other factors.

\section{TEMPORAL INFILTRATION}

“(...) [T]ime and space are not easily distinguishable: space is temporal and time needs space to unfold" (Verhoeff 2012: 145). It is "spacetime" (Verhoeff 2012: 145) which is infiltrated by the urban media. The temporality of media users activity is manifested by tempo, rhythm and merging of past, present and future in daily urban media usage.

\section{“UP-DATED”. TEMPO, RHYTHM AND ACCELERATION}

Urban media are speeding up permanently. The technological development accelerates: emergence and disappearance of new technology takes just a moment. What is more important, the usage accelerates in its mode. Users make a decision to choose a certain technology, adapt it, and absorb it very quickly into their daily practices, as quickly as they change one source or a tool for another. The possibility of urban media usage is also potentially immediate. All that are needed are a device (hardware), an application (software) and usually internet access.

Urban media mediate our daily activities. Mainly mobile media but also stationary media infiltrate our daily practice and therefore determine the tempo and rhythm of our activities. Our physical mobility and virtual mobility is structured by the media. The rhythm of the synchronic physical movement in the city and virtual movement in cyberspace (on the map, LMSN: locative mobile social networks, etc.) is disturbed. The attention and engagement of the user are divided between two spaces: material and digital. That is why the rhythm of the walk is irregular, and the pace is slower compared with those not using mobile media (Labetskaya 2011: 50). Mobile and stable urban media distract attention and stimulate engagement in their structure and content. 
Movement in the city is one of the basic activities of the residents and tourists. We move from point $\mathrm{A}$ to $\mathrm{B}$, less often without any direction, and receive support from the urban media on how to get somewhere, how to get there faster, cheaper or how to find company on the way. But movement accompanies other activities such as work, recreation, and shopping. Most of them are digitally mediatized by mobile media allowing them to search for information, read opinions, write comments, and order online, and to streamline, improve, and enhance those activities. We make our mediatized daily practice more complex by the usage of urban media simultaneously with other non-mediated activity, such as sitting in a park and updating the status on our Facebook profiles. When those activities are not complementary (for example, because the activity of sitting in the park is not connected with the Facebook updates) they are concurrent and make a user do a few things at the same time. Time is doubled or even multiplied, as there is time for both physical activities and virtual activities. Modes of time are layered, but also various and changeable. The time is constructed by the users in their own way in the process of time augmentation. The physical presence of being "here" is augmented by the virtual presence of being "there" in the cyberspace. Time of the material space has its own rhythm and tempo, and the digital activity has specific characteristics. Both are unstable, temporal, and able to intertwine at any moment: "different speeds converge in a place or depart from it" (Brighenti 2011: 405).

In the visual field "augmentation implies changing by adding and combining information. Moreover, it entails an analytic and associative practice - cutting up and making links" (Verhoeff 2012: 148). That is how augmented time is constructed. This is a process of analysis, choosing modes of activity: physical activity, being on the move or stable, doing shopping or watching a film in a cinema; and digital activity like being on Facebook, checking in on Foursquare, or taking a photo with Instagram. And this is a process of association, combining elements from two orders in a simultaneous action, and combining them on a few layers at the same moment. Augmented time is mediatized time, because the molding forces (Hepp 2010: 41) of media structure that time. But this is also media time because it has its evidence in media. Augmented time is hybrid, as is augmented space. It is difficult to indicate the length of time spent in both dimensions, physical and digital. They intertwine during the media usage. It depends on the user's engagement and on cyberspace, which can be estimated only on the basis of recorded time or registered media effects or the effects of time spent online (like on user generated content).

\section{TEMPORALITY AND IMMEDIACY.}

\section{THE MOBILE MEDIA RHYTHM OF EVERYDAY LIFE}

Mobile media accelerate the tempo of many activities, allowing users to reach their goals (like covering a distance, formalities, payments) faster and easier, but sometimes mobile media usage just fills in the time and plays the role of "time killer". Actively waiting for the bus becomes media activity. The passivity of the user in the physical dimension changes to mediated activity in the digital sphere. All activities are temporal: they change during the day but 
also involve a change of whereabouts. What is characteristic of the rhythm of everyday life imposed mainly by personal mobile media is immediacy. This change may take place at any moment and users are used to rapid fulfillment of their expectations. People from one's close environment (family, friends, colleagues) also expect immediate reactions - finding the way and being on time, keeping them informed, responding to a message and such (Fig. 10). When we are on the move we also expect to experience an effective overcoming of distance, taking smartphones and tablets, being more a stalker (the walker with a purpose) than a regular walker (Gazzard 2011: 408). We learn new mobile technologies faster to make all things on the move faster. Just as the visual regime of navigation determines our relations with spaces (Verhoeff 2012: 133), the regime of immediacy defines the culture of mobile media usage (Fig. 11). But as mentioned above, acceleration of media technology development as well as expectations regarding the tempo and rhythm of media usage are accompanied by a slowdown in the physical dimension: people will stop at a point and realize that they are actually on the move. Such movement might be hybrid in its nature, like when the movement of the user is traced on the screen by the user or by other users - this movement is visible in two spaces, or rather in one hybrid converging media space.

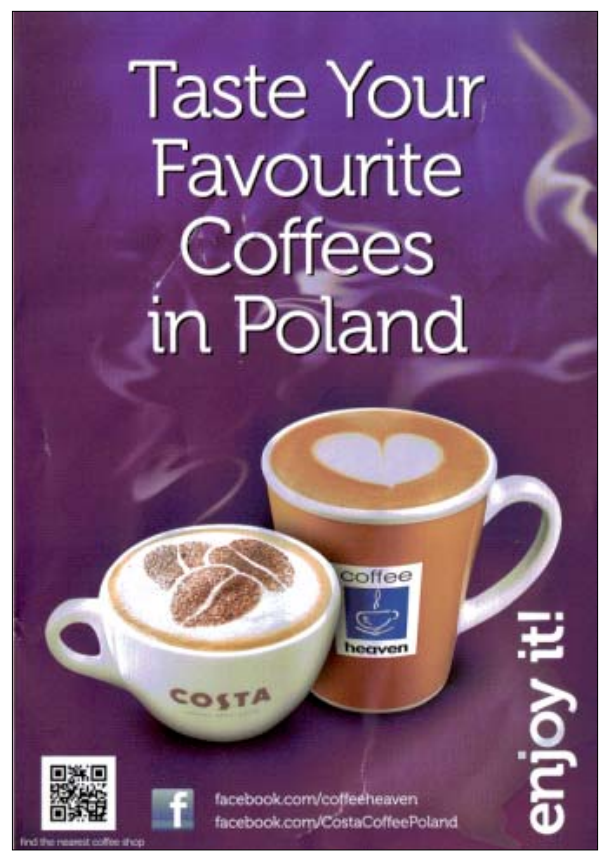

Fig. 10. Coffee Heaven leaflet with a QR code allowing one to quickly find the nearest coffee shop.

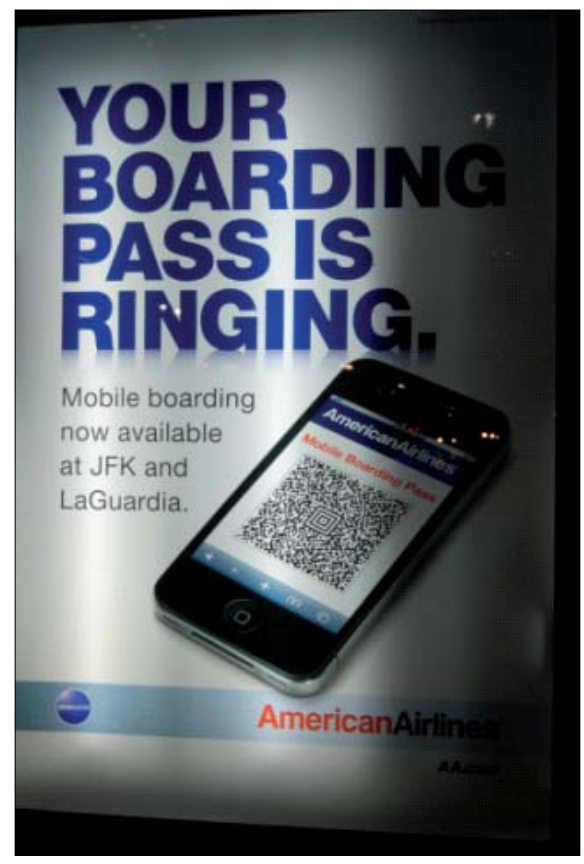

Fig. 11. Citylight promoting mobile boarding by QR code at JFK airport. 


\section{PAST, PRESENT, FUTURE: MOBILITY AND TEMPORALITY}

As mentioned above, urban media, specifically mobile urban media, create a double space or rather multiple spaces. This hybrid space, just as augmented time, is multilayered. We can distinguish the time of physical action and virtual action, which usually intertwine in urban space, but also the time of past, present and future mediated action. Mobile urban media become time hubs - they concentrate on the past, present and future of the user's activity, permanently binding urban places in hybrid space.

[M]ovement through space and interaction with on-screen layers of digital information to off-screen geographical and material presence unfolds in time. But not only does it take time, it becomes over time. A conception of time that includes the productive, or literally creative aspect of time, is relevant here; it includes change in time (Vernhoeff 2012: 163).

Users produce the history of their activity and history of their relations with urban space. The possibilities of future gratification might mobilize them to more intense activity. A past visit to a place might influence them and their social media friends to come back, or not. The best example of building such historical relations and possibilities of augmented time is Foursquare. Users of this LMSN check in to visited places to receive scores and badges. They send comments, photos and share them with others to find the ones nearby or to present their spatial activity. Moreover, they gain commercial benefits like discounts at specific places like shops, restaurants, or cinemas. People create their own strategy to receive a number of points and defeat others in competition. To become a "major" they visit the same place very often, or they try to visit as many similar or different places as possible. They are motivated by the administrator of the service and share their total results with others (Fig. 12, Fig. 13).

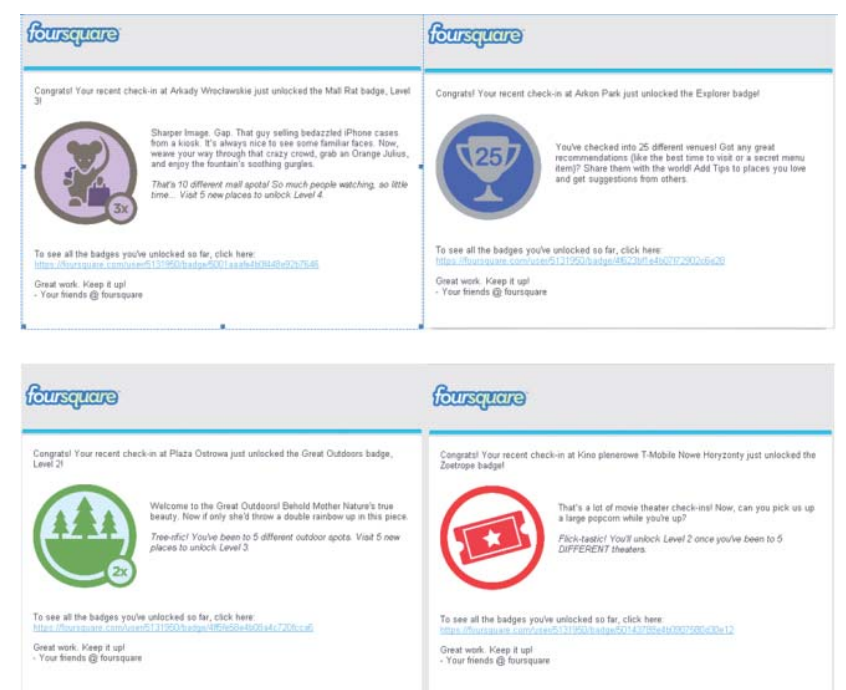

Fig. 12. Examples of e-mail notifications of the Foursquare user. Private mailing of the author 


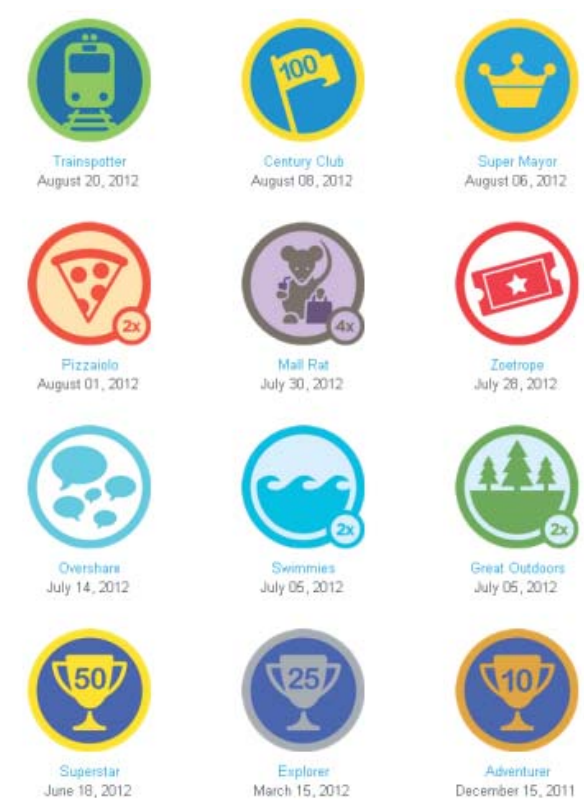

Fig. 13. Examples of budges won by the Foursquare user. Private account of the author. https://foursquare.com/user/5131950/badges/all, 28.08.2012

The core category of urban media usage is mobility. Mobile media usage is increasing and the functionality, form and content of new media depend on the user's mobility. Places become temporal places. Temporality means to divide time and give attention to particular places, both material and virtual. Hybrid spaces and time depend on mobile media usage. The category of engager (Verhoeff 2012: 137) is appropriate here. Creation of hybrid time means participation in a few dimensions via a mobile device. It depends on the engagers, how deep their immersion is in the virtual and physical world, what kind of equipment they have, what kind of application they use, and what their choices and preferences of content are. New solutions enable more and more sophisticated forms of everyday engagement in the city, which will be possibly delivered by Google Glasses.

\section{CONCLUSIONS. CONVERGING SPACE AND HYBRID TIME}

Media infiltration includes temporal and spatial layers. In converging media spaces, hybrid time sets and hybrid time effects occur. Hybrid time sets are constructed within the frames of two axes: the space axis of the continuum of virtuality, augmentation and physicality; and the time axis of the continuum of past, present, and future. The time set is different for every media user, like a mosaic of previous, present and future activities dependent on technology used, urban surroundings and social connectivity (Fig. 14). 


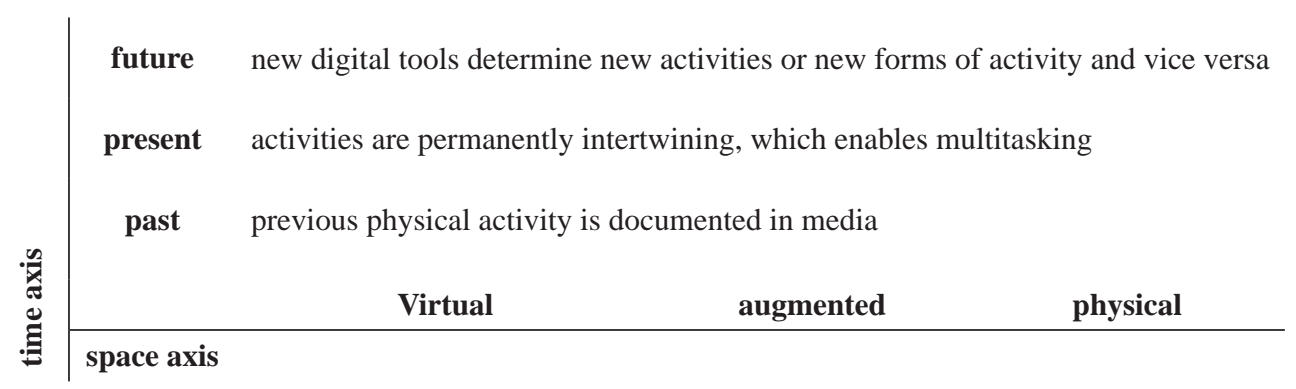

Fig. 14. Potential hybrid time sets

Generally speaking, mobile media usage, new urban media, causes time effects. Hybrid time effects might be as follows:

- multiplication of time by simultaneous actions online and offline

- time compression by improvement of efficiency and accelerating some activities

- time extension by giving possibilities of continuation of offline activity online

- time annihilation by time absorption and losing time due to ineffective usage of media.

Hybrid time sets and effects are fluid and intertwined. Instability is desired. Layers of time are folded. The rhythm and tempo of different activities influence each other, as they are differentiated and changeable. To sum up, being "now" "here" and "there" in the city, using urban mobile media means constructing converging media space and hybrid time, based on portable and stable technologies, used in social contexts and framed by specific mobile media culture (Fig. 15).

\section{URBAN MEDIA}

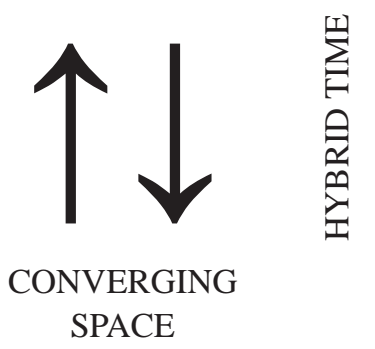

Fig. 15. Creation of converging media spaces in hybrid time by urban media users

"This temporal-spatial navigation is a procedural form of simultaneously making and reading space by exploring a hybrid space of atoms and bits, both the physical and the virtual, through interaction between on- and off-screen navigable space" (Verhoeff 2012: 137). Users, 
by navigating the city engaging in mediated urban activities and creating converging spaces in hybrid time, participate in and stimulate the process of media infiltration. Physical, virtual and augmented infiltration of space and time, resulting in hybridization of both dimensions, are complex processes dependent on technological, commercial, cultural and social spheres of urban life. Today's city becomes a network of physical and digital flows, a patchwork of different technologies enabling connectivity and activity. Ubiquitous computing, Wi-Fi, GPS, RFID, Bluetooth, the Internet of Things, Augmented Reality equipment and other technologies will bring us more functionalities, potentialities of infiltration and effects on space and time relations in a city.

\section{ACKNOWLEDGEMENT}

The research reported here was supported by the Foundation for Polish Science and the Swedish Institute.

Part of the reported research was presented at the ECREA Digital Culture and Communication 3rd Workshop, Digital Culture: Innovative Practices and Critical Theories, Barcelona, 2011 November 24.

Translation from Polish: Katarzyna Kopecka-Piech, Stella Kuśnierz.

\section{BIBLIOGRAPHY}

Bechmann-Petersen, Anja. 2007. Realizing Cross Media, in: Tanja Storsul and Dagny Stuedahl (ed), Ambivalence Towards Convergence. Digitalization and Media Change, Göteborg: Nordicom, pp. 57-72.

Brighenti, Andrea Mubi. 2011. New Media and Urban Motilities: A Territoriologic Point of View, "Urban Studies" 49: 399-414.

Bruns, Axel. 2006. Towards Produsage. Futures of User-Led Content Production, in: Fay Sudweeks, Herbert Hrachovec and Charles Ess (ed), Proceedings: Cultural Attitudes Towards Communication and Technology, Tartu, pp. 275-284, http://eprints.qut.edu. au/4863/1/4863_1.pdf [1.12.2012].

Burd, Gene. 2007. Mobility in Mediapolis. Will Cities Be Displaced, Replaced, or Disappear?, in: Sharon Kleinman (ed), Displacing Place. Mobile Communication in the Twenty-first Century, New York: Peter Lang, pp. 39-58.

Gazzard, Alison. 2011. Location, Location, Location: Collecting Space and Place in Mobile Media, "Convergence: The International Journal of Research into New Media Technologies" 17: 405-417.

Gemeinboeck, Petra, Andy Dong and Francesca Veronesi. 2007. Who Writes the City?, paper presented at the Mobile Media Conference, University of Sydney, Australia, 2-4 July. http:// web.arch.usyd.edu.au/ adong/assets/publications/WhoWritesTheCity.pdf [01.07.2012].

Hepp, Andreas. 2010. Researching 'Mediatised Worlds': Non-mediacentric Media and Communication Research as a Challenge, in: Nico Carpentier et al. (ed), Media and Communication Studies Intersections and Interventions, Tartu: Tartu University Press, pp. 37-50. 
Kluitenberg, Eric. 2006. The Network of Waves. Living and Acting in a Hybrid Space, "Open" 11: 6-16, http://classic.skor.nl/download.php?id=3231 [1.12.2012].

Kopecka-Piech, Katarzyna. 2012. Converging Media Spaces: Introducing an Emergent Field of Studies, "Studia Humanistyczne AGH" 4: 77-91.

Kopecka-Piech, Katarzyna. 2012. Mobile media miejskie, "Studia Medioznawcze" 3: 111-126.

Krajina, Zlatan. 2009. Exploring Urban Screens, "Culture Unbound. Journal of Current Cultural Research" 1: 401-430, http://www.cultureunbound.ep.liu.se/v1/a24/cu09v1a24.pdf [1.12.2012].

Labetskaya, Olga. 2011. Where We Are: Discovery Journey on Nature of Urban Hybrid Space, Master Thesis, Faculty of Architecture and Society, Milan: University of Technology, https://www.politesi.polimi.it/bitstream/10589/23063/1/2011_07_Labetskaya [1.12.2012].

Layar, http://site.layar.com/create/create/ [1.10.2011].

Lemos, André. 2008. Mobile Communication and New Sense of Places: a Critique of Spatialization in Cyberculture, "Revista Galáxia" 16: 91-108.

Lemos, André. 2010. Post-Mass Media Functions, Locative Media, and Informational Territories: New Ways of Thinking About Territory, Place and Mobility in Contemporary Society, "Space and Culture" 4: 403-420.

McQuire, Scott. 2010. Rethinking Media Events: Large Screens, Public Space, Broadcasting and Beyond, "New Media \& Society" 12: 567-582.

Scannell, Paddy. 1996. Radio, Television and Modern Life: A Phenomenological Approach, Oxford: Blackwell.

Schielke, Thomas. 2010. Media Facades: When Buildings Start to Twitter, http://www.youtube.com/watch?v=2uaum8vg60Y [1.12.2012].

Souza e Silva, Adiana and Jordan Frith. 2010. Locative Mobile Social Networks: Mapping Communication and Location in Urban Spaces, "Mobilities" 4: 485-505.

Struppek, Mirjam. 2006. The Social Potential of Urban Screens, "Visual Communication" 5: 173-188.

Verhoeff, Nanna. 2012. Mobile Screens. The Visual Regime of Navigation, Amsterdam: Amsterdam University Press.

Wikitude, http://www.wikitude.org/en/category/02_wikitude/world-browser [1.10.2011].

\section{MEDIALNA INFILTRACJA - MEDIA MIEJSKIE W PRZESTRZENI I CZASIE}

Artykuł przedstawia relacje między nowymi mediami a miastem w wymiarze przestrzennym i czasowym. Proces medialnej infiltracji został przeanalizowany z wykorzystaniem kilku przykładów i ilustracji. Przestrzenna infiltracja została scharakteryzowana z wykorzystaniem stworzonej typologii, tzn. podziału na infiltrację fizyczną, wirtualną i rozszerzoną. W tekście przedstawiony został opis procesów indywidualnej i społecznej semiotyzacji, podobnie jak zjawiska widoczności, niewidoczności i quasi-widoczności elementów medialnych jako typowych właściwości medialnej infiltracji. Refleksja prowadzi do wyjaśnienia złożonych relacji między infiltracją przestrzenną a wyłaniającym się w wyniku użytkowania mediów hybrydycznym czasem. Tempo, rytm i przyspieszenie reprezentują kategorie wyjaśniające złożone relacje między mobilnością, czasowością i przestrzennością. Artykuł stanowi w większym stopniu analityczną eksplorację kreatywnych, społecznych i technologicznych możliwości nowych mediów miejskich i mediatyzowanych praktyk niż krytykę ich skutków.

Słowa kluczowe: nowe media, media mobilne, media miejskie, infiltracja medialna, przestrzeń medialna, hybrydyczny czas 